This item was submitted to Loughborough's Institutional Repository (https://dspace.lboro.ac.uk/) by the author and is made available under the following Creative Commons Licence conditions.

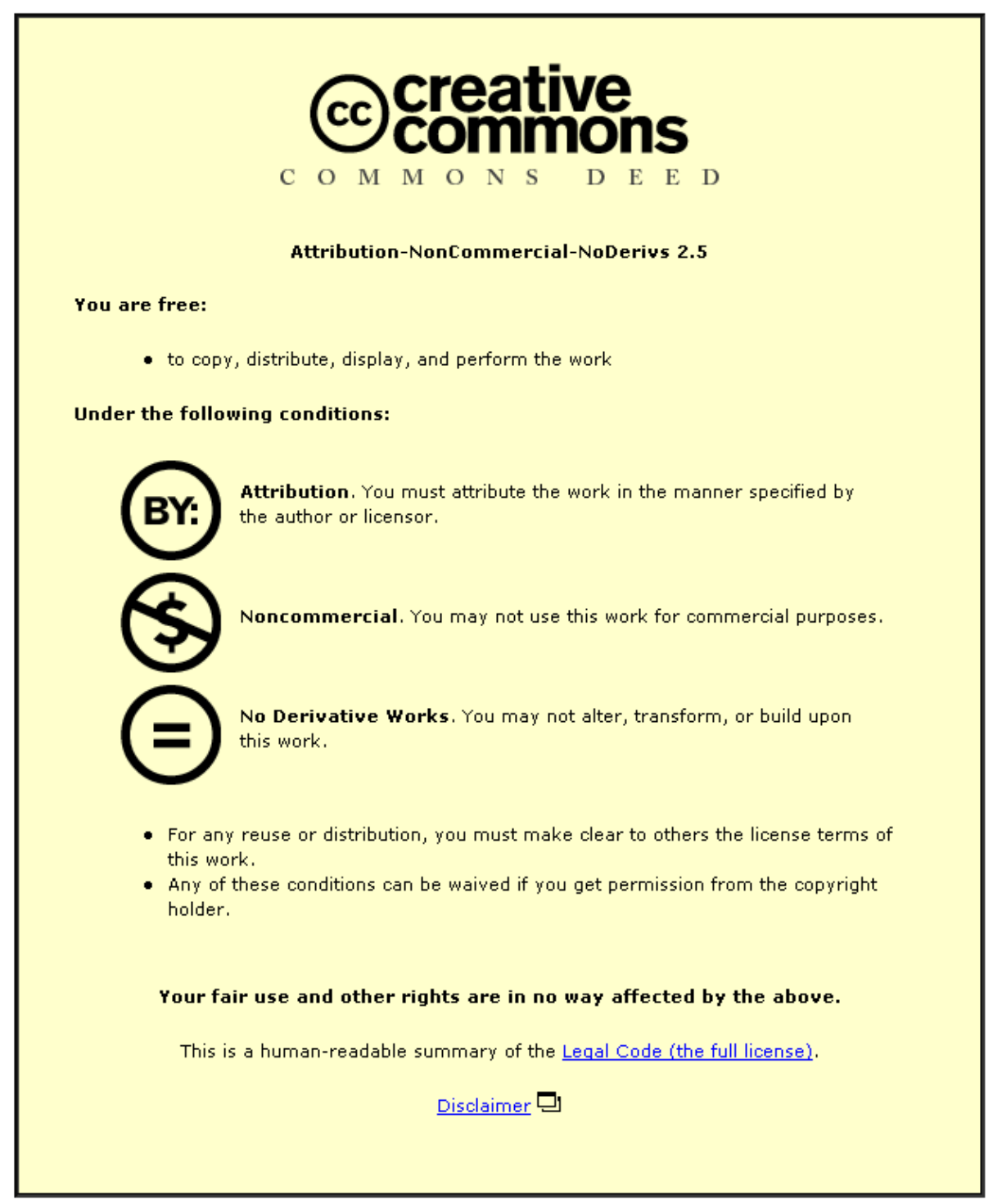

For the full text of this licence, please go to: http://creativecommons.org/licenses/by-nc-nd/2.5/ 


\title{
Learning to be Palestinian in Athens: constructing national identities in diaspora
}

\author{
ELIZABETH MAVROUDI \\ Department of Geography, Loughborough University, \\ Loughborough, LE11 3TU, UK
}

\section{E.Mavroudi@lboro.ac.uk}

\begin{abstract}
In this article I focus on constructions of diasporic national identities and the nation as active and strategic processes using the case study of Palestinians in Athens. I seek, thereby, to contribute to debates on national identity, the nation and long-distance nationalism, particularly in relation to those in diaspora with a collective cause to advocate. I explore how first- and second-generation Palestinians in Athens construct and narrate Palestinian national identities, the homeland and political unity. I argue that the need to 'choose' to be Palestinian, often for political reasons, highlights that the nation is not a 'given' entity. This can be a difficult process for those in diaspora to deal with, as there may be tensions between constructions of political unity and attachment to the homeland and feelings of ambivalence and in-between-ness that may be seen as politically counterproductive. However, I stress that 'messy' and contradictory narratives and spatialities of diasporic national identities that come about as a result of cross-border or transnational (dis)connections do not necessarily lead to apathy and, therefore, can be important.
\end{abstract}

Keywords PALESTINIANS, DIASPORA, ATHENS, NATIONAL IDENTITIES, NATIONBUILDING, SECOND GENERATION

In an interview in October 2003, Tariq, an elderly doctor who has lived in Athens for over 35 years says: 'In 1948, I didn't understand what being a refugee was ... It was here, when I met other Palestinians, that I woke up and realized ... that my homeland ... was Palestine, that I was Palestinian ... my eyes were opened here.' Tariq was born and raised in Jordan and, like many other Palestinians in diaspora, has never visited what he calls Palestine. However, he feels he has learnt to be Palestinian because of his time in Athens and that an integral part of this realization was the process of politicization that came about through contact with other Palestinians in Athens advocating the Palestinian cause, as well as Greeks supportive of the cause. In the same interview, he also talks about having actively to 'remain connected' to Palestine, his homeland (although in reality he is connected to his relatives who live in Jordan) and what he calls his roots through cross-border connections as he feels he is becoming 'more' Greek over time. For him, being Palestinian (and married to a Greek woman) is a dynamic, creative but also problematic process. He knows his life is grounded in Athens but he is also positioning himself continuously between 'here' and 'there', the past (that he has left behind but that is part of his present political imagination) and the future, as he constantly tries to make sense of what being Palestinian means (and will mean) to himself and his Greek-Palestinian children. 
The process of learning to be Palestinian in Athens is often far from straightforward. This is because it entails having to deal with feeling displaced or physically detached, and the need to be attached or reconnected to a territorially defined Palestine. In this article, I address this process but also want to draw attention to what a contradictory, problematic, messy and difficult process this can be. I do so by focusing on the active teaching of national identity to children of Palestinian or Greek-Palestinian parents in Athens and the repercussions of this for teenagers and young adults raised there. In doing so, I wish to highlight the disjointed merging of politicized and cultural narratives of national identity in which notions of home, the homeland, belonging and cross-border or transnational connections or (dis)connections are important. In the process, I argue that it is important that studies on diaspora and transnationalism pay close attention to how such narratives of 'micro-nationalism' (Pryke 2003) or 'bottom-up' nationalism (Hobsbawm 1990) are negotiated and articulated. These are important ways of furthering our understanding of diasporic identities and of appreciating the role of (and difficulties associated with) constructions of nationalism, the nation and national identity in the context of homelandorientated politicization.

\section{Palestinians in diaspora}

Diasporic constructions of political unity, belonging to the homeland as well as the nation, become a way of dealing with connections and (dis)connections, and act as important aspects of politicization and advocacy of the Palestinian cause. According to the Palestinian representation in Athens, many Palestinians support (or are influenced by) the Fateh political movement. This is relevant for this case study because of the historical relationships between Fateh, the PLO and the emergence of a defined Palestinian nationalist movement. Fateh proposed 'a Palestinian national ideology in which Palestine would be liberated by Palestinian action, with Palestinian refugees taking matters into their own hands' (Baumgarten 2005: 32). Bowman (2003: 335) also stresses the role organizations such as the PLO play in evoking the 'banner of the nation', which 'enabled Palestinians in various sites and states to imagine their differences subsumed within the programme of liberating "Palestine"'. Therefore, such an underlying discourse can be seen as an important aspect of the construction of Palestinian national identities and political unity in Athens. Although many do not see themselves as overtly politically active, they are politicized and appear influenced by such narratives. For many participants, politicization revolves around advocacy and support of the Palestinian cause. This entails the end to Israeli occupation of the West Bank and Gaza, self-determination and the creation of a Palestinian state as well as the Right of Return for Palestinian refugees and a solution to the issue of Jerusalem.

The Palestinian cause is directly related to what Palestinians call the 'Nakba' or catastrophe in 1948, the year in which the Palestinian diaspora was created alongside the advent of the state of Israel. The little research on Palestinians living in diaspora that has been conducted revolves around constructions of cultural and political identity, belonging and imaginings of, as well as cross-border connections with, the homeland (see, for example, Aoudé 2001; Dorai 2002; Shiblak 2000). 
This article adds to this body of understanding through qualitative research, carried out in 2003-2004. Over a period of nine months in-depth interviews with 54 Palestinians of diverse backgrounds and ages were conducted, including foreign company employees (abbreviated as FCE throughout), doctors, casual workers, students and registered refugees (of which there are only a few). There are roughly 4000 Palestinians currently in Athens, according to the Palestinian representation there, but because of the lack of statistics and research on Palestinians in Greece, it is currently not known how many there are in the whole country. Many are first generation migrants in the sense that it is they who made the move to Athens but there is also an emerging second generation. Most Palestinians appear to have started arriving in Greece from the 1980s (for more on this and the different Palestinian 'groups' in Greece, see Shawa 2005). The majority of participants were Muslims although there are also Christians. However, they seem to perceive themselves as Palestinians, and most view versions of Palestine as their homeland. Overall, Arabs in Greece appear to be 'hidden', an observation also made by Nagel (2002) with respect to Arabs in Britain.

According to Lindholm Schulz (2003), the condition of being Palestinian in diaspora is 'to move'. Living in Athens, Palestinians often cannot avoid mobility because they have had to move, often more than once. However, they also experience realities of stasis, often aided by the fact that they are stateless and can have an ambiguous and complicated legal status because, like all foreigners in Greece, it is difficult for them to become Greek citizens. As a result, most are not Greek citizens, residency is often insecure and travelling difficult (for more on the relationships between citizenship and national identity relating to Palestinians in Athens, see Mavroudi forthcoming). Therefore, in terms of physical cross-border connections, many Palestinians in Greece have to rely either on sporadic trips to Palestine, trips to the wider Middle East that are for some, more regular, or no trips out of Greece at all. The majority, however, rely heavily on cross-border communications in the form of the mass media (through satellite television), the Internet and regular phone calls to family and friends in Palestine and the wider Middle East (for more on such communications and the role of the media, see Hanafi 2005 and Matar 2006). Although there are only a small number of Palestinians in Athens, it is a useful site for research for several reasons. First, it provides much needed additional research on Palestinians in diaspora outside the Middle East and on how diasporic national identities are negotiated. Second, Athens, despite being outside the Middle East, is an interesting location in which to carry out research on Palestinians because of its position between the Middle East and Europe. Third, the fact that they appear to have had an easier time than other migrants in Greece in terms of the popular and governmental support they have received (Smith 2002) has provided a useful backdrop for constructions of Palestinian identity and unity in Greece.

\section{Diaspora and the imagining of the nation}

Notions of diaspora are often based on the idea of movement or dispersion away from a homeland that is subsequently kept alive by forms of physical and/or emotional transnational or cross-border connections to the homeland and to others in diaspora. 
Likewise, transnational migrants are often seen as dependent on the ability to create transnational networks to their country of origin (Glick Schiller et al. 1999; Guarnizo and Smith 1998; Portes et al. 1999). There have been numerous attempts to explain the consequences and repercussions of such cross-border (dis)connections on cultural notions of diasporic and migrant identity as well as home and belonging (see for example, Al-Ali and Koser 2002; Blunt 2005; Clifford 1997; Hall 1999; Kennedy and Roudometof 2002). There have also been attempts to assess the geopolitics of diaspora (Carter 2005), transnational and diaspora politics (Itzigsohn 2000; Østergaard-Nielsen 2001, 2003) and the construction of long-distance nationalism, which focus on how national identities are created from afar using transnational/crossborder relations. Such discussions are useful but there is a need for more research on how different individuals and generations within diasporas strategically and actively construct diasporic nationalism in relation to political and cultural identities.

Deliberations on long distance nationalism include the work of Skrbis (1999) and Anderson's (1992) warning of extreme nationalists participating in potentially violent homeland politics from afar. The work by Glick Schiller and Fouron $(1999,2001)$, who analyse the transnational relations between Haiti and the USA and warn against extreme forms of long-distance nationalism, is also important. However, long-distance, transnational or diasporic nationalism does not have to be extreme and, though some people in diaspora may have constructed more homogenizing and exclusive notions of national identity, it is necessary to examine why and how such constructions occur. To do so we need to acknowledge that, like cultural identities, diasporic national identities are actively constructed.

Although some scholars have seen the process of nation building as part of the modernist era (for example, Gellner 1964, cited in Croucher 2003), the active construction of nations remains important in contemporary times. However, according to Thompson (2001: 21), sociology, at least, has paid very little attention to the practices of nationalism and the nation, or how 'individuals actively employ their "common stock of knowledge" about nations and national identities'. He also stresses that 'an important consequence of these practices is that the nation is objectified: people learn their nation's history, they can forget and then again, remember their national identity and they can express this national identity'. Thompson also points out that in traditional notions of the nation there is little room for active deployment and use of imaginings of the nation; they are often seen as 'given' or 'natural'; the same may be said of notions of diaspora that continue to accept ideas of ethnicity, religion and national identity as given. However, one could see such a deployment as an active strategy whereby individuals 'choose' the nation to which they want to belong and one cannot ignore their political reasons for doing so.

A potential reason for the 'relative neglect of émigré nationalism and its impact' (Bhatt and Mukta 2000: 407) may be the association of nationalism with the nation and nation-state, as a territorially bound notion and it is such relationships that diaspora, with its emphasis on dispersion and fluidity, is often seen as weakening. As 
Dirlik (2006: 241 citing Tölölyan 1991: 5) has noted, 'the nationalism in diaspora discourses is often noted but not elaborated and is certainly overshadowed in most discourses by a sense of diaspora as the "other of the nation-state"'. However, although some academics feel that the nation-state may be weakening (Soysal 2000), the nation, despite being a 'slippery' idea, remains important, particularly to those who are 'fighting for a state of their own' (Croucher 2003: 17). As Yeoh and Willis (1999: 357) also note, there are 'new strategies ... to reaffirm "indigenous", "ethnic" or "cultural" identity rooted in place (including new invocations of the nation)'. Therefore, the imagined nation as a form of belonging and identity can be seen as central to diasporic political demands for statehood or autonomy.

People in diaspora, 'on the move', can be seen either as disrupting the hegemony and imagined homogeneity of the nation-state through their fluid, multiple and/or hybrid identities, or are implicitly analysed as defined ethno-religious groups neatly dispersed around the world (for more on this, see Cohen 1997). This can make it difficult to analyse the active and strategic constructions of national identity in diaspora, which may form an integral aspect of diasporic identities. It is important to realize that 'social identities may be reconfigured in different ways in a transnational context: they may become ambivalent, partial, multiple, hybrid and contradictory, but they may also be reinvented as primordial certainties' (Aguilar 1996, cited in Yeoh and Willis 1999: 357). Soysal (2000: 2) notes that 'the dominant conceptualisations of diaspora presumptively accept the formation of tightly bounded communities and solidarities (on the basis of common cultural and ethnic references) between places of origin and arrival.'

In this article I attempt to deconstruct this idea by arguing that, because such 'cultural and ethnic references' are actively and strategically constructed, they cannot be seen as 'given'. However, we also need to be aware of the strategic ways in which those in diaspora construct notions of ethnic, religious and national communities and identities that become important to their daily lives, experiences and feelings and are taught to future generations. It is important, therefore, to move beyond different notions of diasporic identities as either multiple/hybrid or ethnic-religious and to recognize the instability of political, cultural and national identities in diaspora. As Brubaker (1996: 13) has noted, it is important to stop analysing nations as 'stable axioms of being'. Nevertheless, such imaginings of the nation as momentarily homogenous and stable continue to be important, despite their unstable nature. One can see the role of bringing up children to be Palestinian in diaspora as part of the process of imagining and creating a Palestinian nation where notions of national identity, unity, ethnicity and so forth are actively invoked for political reasons. Such teachings invariably arise from the parents' constructions of what it means to be Palestinian in diaspora, the cross-border connections or (dis)connections they may have and the fact that they have chosen to see themselves as Palestinian, even when they may never have visited Palestine. As Bowman (1994) remarks, Mahmud Darwish's poem We travel like other people points out that Palestinians have a 'country of words'. Said (1990) has stressed that Palestinians have nourished what he calls their 'national identity' in exile. With the lack of an official state, such words 
and narratives may allow Palestinians to continue feeling Palestinian in diaspora. Bowman (1994) also notes that there may be what he calls a plethora of particular strategies for creating such a Palestinian nation. However, he also points out that as a result there is less of a unified 'nationalist movement' because he claims that each Palestinian community in diaspora is relatively separate from one another; it is this that has allowed varying and potentially competing and antagonistic narratives of what it means to be Palestinian. Such perceptions and representations of difference (and sameness) can also be seen within Palestinian diasporic communities as they actively struggle to define the nation and/or the national for themselves and their children through their articulations of belonging, unity and the homeland. In this article I will attempt to illustrate the difficulties involved in doing so, drawing attention to what Werbner (2000) has called the 'daily materiality' of diaspora and what Thompson (2001) has called the 'untidy' processes of how individuals come to construct national identity in relation to one another. To do this, I will first focus briefly on some first-generation constructions of what it means to be Palestinian; then go on to discuss how this translates into active parental 'teaching' of children to be Palestinian. Finally, I explore how some teenagers and young adults (with at least one parent being Palestinian), raised in Athens, articulate being Palestinian.

\section{Palestinian national identities in diaspora: first-generation narratives of political unity and ambivalence}

In his book Palestinian identity Rashid Khalidi $(1997: 9,205)$ asks 'what are the limits of Palestine?' With this important query, Khalidi illustrates the ambivalence and difficulty, as well as the perceived potential political strength, of defining a bounded Palestinian homeland and nation. He also highlights the important role the homeland plays in Palestinian diasporic identities and belonging. However, as Tariq's example at the beginning of this article highlighted, notions of a Palestinian homeland and belonging have to be actively learnt and there are numerous ways of triggering feelings of a shared identity or nation. For example, Khalidi (1997: 194) has argued that certain events, such as the Nakba and its ensuing trauma and dispossession have 'cemented and universalised a common identity' among Palestinians. He also points out that 'if the Arab population of Palestine had not been sure of their identity before 1948 , the experience of defeat, dispossession and exile guaranteed they knew what their identity was very soon afterwards: they were Palestinians.' However, rather than) accept such a Palestinian identity as given, it is important to consider how such feelings of nationalism are actively maintained in diaspora in relation to cross-border connections or (dis)connections, as well as changing situations in the host country or homeland. Ghada Karmi's (2002) autobiography of identity, ambivalence and activism while living in the UK is an excellent example of this.

In Athens, perceptions of injustice and suffering often form part of what it means to be Palestinian. Although, Abir, an Arabic teacher, is ambivalent about her feelings of home and belonging, she is also politicized and politically active. She has, therefore, constructed herself as Palestinian as a result of:

My family and the situation there, the fact that I was born there; that I am from 
there originally, that my parents are from there and the unfairness, the injustice there, that there is always something wrong with the situation ... there is this obsession when you don't have a country, when you can't go back and when you feel that you and your family had something that was taken away from you which makes Palestinians even more united and makes them feel that they are Palestinian even more. If all this is solved, you won't have this; it won't be the same.

Relationships to the homeland, as well as constructions of unity and solidarity, form a large part of diasporic existence. For example, many regard the historic homeland as the symbolic and political glue that holds displaced diasporic peoples together, within a nation, especially those without a nation-state. According to Lindholm Schulz (2003: 9), diasporas need to have 'strong collective images of the homeland', which may be constructed for political reasons because a defined territory is seen as necessary to strengthen constructions of political or 'fictive unity' (Robins and Aksoy 2001) as a prerequisite to feelings of nationalism needed in a future state. Constructions of the homeland play a role in specific and politicized discourses of Palestinian identity and unity in diaspora. For example, Layla (FCE) believes that 'outside Palestine, we have to be really united.' Like Abir, she has come to feel that Palestine is her territorial homeland, not only while she is in diaspora in Athens but also in the other Middle Eastern countries in which she has lived. It is a homeland to which she feels she belongs and one that unites her with all other Palestinians in diaspora as well as in the West Bank and Gaza.

Although politicized representations of Palestine can appear static and 'given' as a result, it is important to remember that living in Greece requires Palestinians constantly to verify that that they are Palestinian (in their interactions with others, including other Palestinians). This they do via active 'searching' for what they see as their Palestinian roots, or the concrete ties that 'bind' them to Palestinian soil or territory. For Palestinians whose families fled from what is now Israel in 1948, this is sometimes done through descriptions and narratives of ancestral villages and the material houses their family once occupied, that are told and retold. For example, in response to a question asking him where he felt he was from, Majid, a middle-aged FCE says:

I am from Palestine, from Safad, which is to the north. My grandparents left in 1948. Well, my grandfather didn't. He refused to leave his home and his land and so he was killed. The rest of my family went to Lebanon where things are very difficult for the Palestinians. ... The village I come from is close to the Golan Heights, on the side of a mountain. It is a green area and my grandparents always described how beautiful it is. I always wondered, you know, if it was actually as beautiful as they described. But when I was in Canada I was in this fast-food place and I saw an employee with the same surname as me. I asked him where he was from and he said Palestine. It turned out that he was originally from a village close to mine. And some time later, I got a parcel in the post. It was a video of the area where I come from and of 
my village as well. And it looked so beautiful in real life. ... It was very emotional actually seeing the piece of land that I came from and I asked my parents for all the information they had on it, the dimensions and the exact location so that I would have a clear idea of it in my head and I have a large file full of information on it (laughs).

Majid's constructions of national identity occurred in diaspora in Lebanon, Canada and finally in Greece as he actively continues to search for information about what he perceives is his homeland in order to remain connected to it as a potential means of dealing with the insecurity that movement may bring.

Palestinian searches for roots, identity and connections to Palestine while 'moving' in diaspora may be seen as reminiscent of what Yeoh and Huang (2000: 415) have called 'diaspora journeys' that are 'neither purely emancipatory nor reactionary: instead they are provisional, dependant on the confluence of circumstances and continually elude foreclosure' and are 'ridden with disruptions, detours and multidestinations'. Unsurprisingly, as Bowman (2003: 82) stresses, "'Palestine" will be imagined differently by Palestinians in different situations'; in other words, he stresses that Palestine is an active, dynamic spatial and temporal construction. Despite this, many Palestinians in Athens view the idea of a shared Palestine and national identity to which they can all relate in some way and over which they can unite politically as important. However, at the same time, the need to achieve such shared identity can overshadow the many personal feelings of ambivalence, confusion and detachment from Palestine that may also be experienced.

Although many discussions of diasporic identity highlight the role of multiple, fluid and ambivalent identities, it is important to understand that ambivalence and fluidity may also have an important role to play in constructions of diasporic national and political identities. The tensions or disunities that exist when those in diaspora with a cause to promote try to deal with personal feelings of detachment, ambivalence, disunity or disillusionment sometimes get forgotten, hidden or ignored, or if they are mentioned, they are perceived in negative terms as detrimental to the cause.

Thinking about and defining Palestinian national identities and the homeland is often fraught with tensions, confusion and ambiguity for Palestinians in Athens. Edward Said (1986: 30) lucidly describes how difficult such notions are for Palestinians in diaspora to articulate:

Palestine is exile, dispossession, the inaccurate memories of one place slipping into vague memories of another, a confused recovery of general wares, passive presences scattered around in the Arab environment. The story of Palestine cannot be told smoothly. Instead, the past, like the present, offers only occurrences and coincidences. Random.

However, the need for political unity, national identity and self-determination has encouraged the 'smooth' and orderly reading of Palestine and of the Palestinian pasts. 
At the same time, learning to be Palestinian in diaspora involves accepting that, despite the need for order, relationships to the homeland as well as notions of home and belonging are often problematic, fractured and disjointed. Therefore, it is not surprising that, despite political constructions of Palestine as the homeland, Palestinians in Athens express ambivalence and detachment while discussing notions of home and national identity. For example, Faeq, a FCE in his forties who has lived in Greece for more than 15 years but who moved around the Middle East a great deal beforehand, stresses that:

I have a homeland and a home in Palestine. I came here originally for two years and I have stayed for 15 . My identity is problematic. What does living here do to your identity? Mmmm, I think it's insecurity that plays a large role, the issues of where to go, where to settle - or where you can go and where you are able or allowed to settle, like for example, what my parents had to go though. They have been travelling and moving around their whole lives. When you get to a certain age, you want to build a home to retire in - God knows where I will retire.

The fact that he feels his identity is problematic signals that he is having actively to construct what it means to be Palestinian, 'on the move' but with a homeland and nation he feels he has to remember and be faithful to. Likewise, Rafiq, who has lived in Greece for over 20 years (and has not been back), feels he has experienced changes in identity:

Sometimes (pause) ... I do feel Greek and that Greece is my home - I have been here so long but I know that's wrong because I am Palestinian and I do feel Palestinian too but it's hard not being there. I want to be there so much but at the same time, it's good here.

On the one hand, he feels he must be committed to remembering Palestine and the cause (as well as his family in Gaza) but on the other, he is confused about his identity, which he finds difficult to deal with.

The idea that the nation to which a person belongs is 'given' ignores the very real and material processes and feelings of ambivalence, insecurity and sadness involved in such constructions of the nation that many in diaspora may find problematic or difficult to deal with. This may especially be the case when it is difficult physically to visit a homeland. This is the reality for many Palestinians, who may be unable to visit the place they perceive as their home, either in what is now Israel or in the Occupied Territories. Such a lack of physical connection has implications for constructions of the nation and it often appears that feelings of detachment go alongside feelings of attachment seen to be needed for political unity and politicized national identity. One needs to see active constructions of diasporic nationalism and national identity against a backdrop of emotion, attachment and detachment to the homeland. In exile, positive feelings of political advocacy, unity and politicization often go hand in hand with negative feelings of grief, loss and suffering that also need to be 
negotiated and handled. As Ashcroft and Ahluwalia (1999: 139) point out, this can lead to the need for survival and flux and an appreciation that 'here' and 'there', past and present may merge in disjointed ways:

Exile does not mean the total separation from your place of origin but is rather a condition where one never abandons the old nor completely accepts the new. It is not a state in which one can become completely comfortable and secure. Rather it is a state that hones your skills for survival.

Such a concept of survival may also be closely related to notions of the persistence of diasporic national identities through time and space, which may be seen as the result of the difficult but necessary teaching of future generations to be Palestinian.

\section{Teaching children to be Palestinian: 'difficult but necessary'}

The notion that children have to be actively 'taught' how to be Palestinian from an early age is one that many Palestinians in Athens see as important because they perceive it as a way of ensuring the continuation and survival of Palestinian national identity and connections to the homeland in diaspora. In a nation-state, education systems play a vital role in such constructions (Gellner 1983; Howard and Gill 2001) as do the media, such as the print media (as discussed by Anderson 1983), television or the Internet. In the absence of the former, the latter provide ways of uniting those in diaspora. However, less attention is paid to the role of parents and to how they raise their children to feel and act in a certain way. Although Billig (1995) has pointed to the presence of 'banal nationalism', it is also necessary to examine how such banal symbols such as flags and so forth are used and can take on great significance for those engaged in long-distance or diasporic nationalism with a politicized cause to promote. For Palestinians in diaspora, the family has been seen as a 'weighty institution in creating a Palestinian identity in exile' (Lindholm Schulz 2003: 172, citing Sayigh 1977) and this also seems to be the case for Palestinians in Athens, as 'younger generations become part of the narrative produced by their parents' (Lindhom Schulz 2003: 172).

Many Palestinians in Athens believe that educating their family about their national identity and belonging results in 'ten-year-old children know[ing] more about politics than adults. They grow up with politics; their whole life is politics' (Mahmud, student). Despite having no children, for Mahmud, the politicization of children in diaspora is significant, for, as the next generation, they are responsible for keeping the Palestinian cause alive. Faeq, an FCE married to a Palestinian and a father of two notes, 'they are the key to the future ... the next generation will be more committed.' The upbringing of children in Palestinian families and the instilling in them that they are Palestinian is as an important investment for future advocacy of the Palestinian cause, as is the hope that arises as a result of such actions. As Rafat (FCE) points out:

For me, my children and the children of my friends, who are born in Greece and who live here, we need to teach them Palestinian history, to keep them close to the cause, so that they live and understand it, so that we can guarantee 
that if our generation does not achieve our goal, the next generations will be able to. This is a very important job we have outside Palestine.

Layla, an FCE in her thirties, has similar feelings. Like Rafat, she has constructed the need to teach children to be Palestinian as an ideal she and other Palestinians have to attain. As a result, such teachings have become an accepted part of what it means to be Palestinian in Athens: 'If you are a good person, you will raise good Palestinians and a new generation ... also I have to tell my children about Palestine and if I am a good Palestinian I will.' As I was interviewing Layla, her eight-year-old son appeared and sat with us for a while. She said: 'Ask him, ask him about Palestine, he knows everything. I've told him everything; he knows where he is from.'

Although Layla does not appear to acknowledge any difficulties in the process of teaching her son to be Palestinian, many other Palestinians do. For example, Rania, a well-off Palestinian executive with two children who go to an international school, often has to deal with her own perceptions of difference and the need to control her own negative feelings towards Israelis when her children talk about their Jewish Israeli friends at school. She feels she tries hard to teach her children to respect others but finds it difficult to do so because of her own feelings. Nonetheless, she takes her role as a Palestinian mother who needs to teach her children to be Palestinian seriously, particularly as the father of her children is Greek. At the same time, she is aware that, because her children associate with non-Palestinians, they will have to negotiate what it means to be Palestinian and that she has to help them in this process. Ahmed (FCE) and Maha (housewife) also discuss how difficult they feel it is for Palestinian children at schools in Athens; this is because children have actively to make a political statement about their notions of national identity:

Ahmed: Now this with our kids, we are really facing problems, when it comes, lets say, like with the Olympic Games, they say, why don't we see Palestine? They go to the school, Nabil, who is nine years old, they have posters, flags and maps of all the countries and he was searching for the Palestinian flag and he never found it and then what he did was he drew it on a piece of paper and stuck it there. He got approval from the principal and he stuck it there together with the other ones because he was feeling bad about it.... The issue of identity is really ... for me, I long to hear our Palestinian anthem, to see the Palestinian flag, we never felt this before and I think our kids are getting to this stage where they really feel.

Interviewer: So you are teaching them to be Palestinian?

Ahmed: Of course.

Maha: My daughter when she's angry, she says, I hate you, I hate dad, I hate the cat, I hate the house, I hate everybody, but I don't hate Palestine and God (laughs). 
Maha and Ahmed illustrate the difficulties involved in such politicized negotiations of what it means to be Palestinian (and of belonging to a homeland called Palestine but not an official country) to them, and to their children. Although Ahmed was born and brought up in Syria and has never visited Palestine, it is clear that he thinks it is important that his children feel Palestinian, like he and his wife (who was born and raised in the West Bank) do, despite the difficulties they may encounter in the process.

Many other mothers such as Sana, a housewife in her thirties, for example, feel the same and find such teachings necessary, but problematic at times because of living in diaspora, away physically from the homeland and having to rely on cross-border connections such as the mass media:

I teach my children about Palestine, about what is going on there. I let them watch the news and they get scared and they say they don't want to go there. So perhaps it's wrong that I show them, but I want them to know, to see the suffering. And, they have Israeli friends at school and they say mama, but they're not bad as the ones we see on TV, because they don't have guns and I said, when we talk about Israelis, we talk about Israelis inside Palestine, not outside.

The active and strategic process of teaching children to be and feel Palestinian is, therefore, far from straightforward and is conducted in relation to cross-border connections and (dis)connections, Greek contexts, the mass media, as well as their own feelings of politicization and commitment to political unity and the cause. It is tempting to discuss such teachings as ways in which women are taking on the role of narrating the nation. Much has been written about such potentially static roles that may be expected of women and the relationship between gender and nation (see, for example, Yuval-Davis 1997). It is difficult to analyse such notions adequately in relation to Palestinians in Athens; both Palestinian men and women seem concerned with future generations and the role that upbringing plays. However, although some may perceive that it is the role of the mother to create a Palestinian home and raise Palestinian children, there was not enough evidence to suggest that this was something Palestinian women found problematic. Neither did they seem to feel that their place was 'in the home'; however, the need to be politicized and to help the cause in some way may help persuade them that the raising of Palestinian children is a viable and important way to do this. Hala, for example, has three girls and works full time. Although she is very busy, she is clear about the role she has to play to help fellow Palestinians. Not only does she get involved in charitable work (as do many other Palestinian mothers) but she is determined to have as many children as possible as she sees this as a deliberate strategy employed by mothers in the Occupied Territories that she admires. She also feels that this is an important way to continue Palestinian national identity into the future. However, it is also important to explore the result of such teachings for children who have grown up in Greece. 


\section{Palestinians growing up in Athens: the second generation and complex imaginings of diasporic national identities}

There has been some interesting work on the role and importance of the second generation in research on transnationalism and diaspora especially in the US context (Portes and Rumbaut 2001; Levitt and Waters 2002). Research on the second generation has focused on a number of factors such as the impact of return to the homeland (Christou 2006), racialized and religious identities (Kurien 2005; Rassool 1999), notions of home (Dwyer 2002), and their impact on host and homeland societies, where identities may be seen as problematic, flexible and dynamic. In this section, I attempt to make a modest contribution to this research, of which more is needed.

Rather than being 'comfortable with multiple and multifaceted identities' (Rassool 1999: 35), the second-generation Palestinian young adults and teenagers to whom I spoke in Athens seemed to find their identities difficult and problematic. As noted above, the second generation is invested with the ability to continue the cause into the future by the first generation through 'remaining Palestinian'. However, talking to this second generation reveals that, like their parents, they often feel torn between the need to maintain strategic constructions of more idealized and homogenized versions of Palestinian national identity and their own feelings of ambivalence and inbetweenness.

The fact that Palestinians continue to be stateless and experience feelings of insecurity and injustice must also be take into account. Learning to be Palestinian without a state-sponsored education system has meant that, like their parents, teenagers and young adults often feel they have actively to decide and choose to be Palestinian as a result of their interactions with non-Palestinians at school, their upbringing and the cross-border connections and (dis)connections they have with Palestine and the wider Middle East.

Being grounded (and growing up) in Athens can change, complicate and detach relationships to the homeland and lead to the realization that being Palestinian in Athens, with what are often confusing and difficult notions of home and belonging, is different from being Palestinian in the West Bank, Gaza and the rest of the Middle East (and different to their parents). A discussion with 17-year-old Dina illustrates how the process of becoming Palestinian is often fractured and ambivalent, as well as attached to and detached from Palestine. Dina, who has grown up in Athens, vividly depicts such issues in her recollection of a visit to the West Bank, from where her father came and to which she was sent specifically to reconnect with her roots and homeland:

the little things ... going hunting with my uncles in the middle of the night. It was in the middle of nowhere. It was a different world. I remember the Israeli troops were always trying to come into the town. I remember feeling like an outsider. The other kids were really aggressive, throwing stones ... but eventually we became part of it. I realized that the land was rooted in us, so we 
were related to it in the end and I found myself throwing stones ... another time, I was sitting on the steps of my house there in my shorts and T-shirt and a young Palestinian girl came up to me. She was fully covered. I can't remember exactly what she said, but she disapproved of what I was wearing. I couldn't understand why she and others were like that. I respect what they choose to wear and they should respect what I want to wear. I am Palestinian, but I have grown up in Greece, so I am different I suppose and this has influenced me. But I try to understand them, so they should try and understand me and what being Palestinian means to me.

Dina's visits to the West Bank are etched in her memory and have altered her perceptions of what it means to be Palestinian over time and space, which are both problematic and positive for her. Although she has connections to Palestine through her father, (and because she has visited it) her upbringing in Athens and close ties with her mother (and Lebanon, from where her mother comes) have diluted her perceptions of Palestine as her homeland. Dina is content to live in Athens and has friends from all over the world as she goes to an international school. However, her ambivalence about her feelings of home and belonging as a result are evident:

I'm starting to think about being Palestinian more as I get older I think.

Sometimes it's hard not to though because of my father and what he tells me about the situation there. But it's not something I think about all the time. Well, I accept the fact that I am Palestinian I suppose, but it's also hard, because I was born here and I grew up here and my friends are not Palestinian. I really don't know actually. I'm really not sure.

Dina is beginning to acknowledge that she feels 'in-between' and has political feelings based on her particular upbringing and immediate surroundings. As she tells me about a project she carried out at school on the situation in Palestine, she explains her satisfaction in being able to find out more about her roots and admits that she has a great deal more to learn. These are actions she feels will enable her to tell people about the historical and political situation in Palestine, something she does not feel confident doing at present. Her brother Omar, a student, appears more certain about his constructions of national identity that he thinks have grown stronger because he feels he has gone through a period of 'political awakening' at university, as he has started to read more and think about the situation in Israel/Palestine but admits that he has moments of ambivalence and insecurity about being Palestinian in Greece. The second generation may also appear more willing to discuss the difficulties associated with feeling ambivalent and in-between even as they acknowledge the importance of constructions of political unity and a national identity that may appear homogenized and based on 'solid' attachments to Palestine they find problematic. This can lead to tensions and contradictions in their own articulations of what it means to be Palestinian. For example, Jamila, a student who was born in a refugee camp in Lebanon, but has grown up in Athens, is politicized and active within the General Union of Palestinian Students (GUPS). She feels that 'I, who have never lived there, feel much more intensely the Palestinian blood that runs through my 
veins. Because I haven't lived there, it's much more intense for me.' Therefore, separation and exile can appear to breed very strong feelings of belonging. However, Jamila's perceptions of home are also very difficult for her to articulate and come to terms with. In the same interview, she says:

where is my home? [silence] I feel that inside me, there's a metal, which has two ores in it. There are two things inside me, Greek and Palestinian ... I can't say I'm fully Greek, because I feel more Palestinian than Greek, but I also feel both Palestinian and Greek. I have to remember Palestine because it's like an open wound.

The case of Sa'id, a student born in Jordan who has grown up in Greece and is a member of the GUPS, is another example. He finds the question of where his home is 'very tricky' and it is something about which he feels ambivalent. However, since he is politicized and has become more so since being a student studying political science (a strategy to enable him to do something concrete to help the cause in the future), he still feels he belongs to historical pre-1948 Palestine, and points out the importance of Palestinian political unity despite the diversity that inevitably exists in diaspora. The idea of 'unity in diversity' that some Palestinians in Athens articulate goes hand in hand with the notion that people can come together for strategic purposes at particular times (and in particular spaces) and can create more essentialized identities based on notions of ethnicity, religion and nationalism in the process. Therefore, to create change it is seen as acceptable for people such as Palestinians to essentialize their 'imagined communities' (Anderson 1983) and national identities. As Lavie and Swedenberg (1996: 12) point out, 'essentialism is a political necessity, particularly when the group or culture is threatened with radical effacement. Hybridity therefore does not appear to be a viable strategy for Palestine.' However, as Hall (1999: 303, 302) indicates, 'identities are not an essence but a positioning.' Hence, there is always a 'politics of position' that 'far from being externally fixed in some essentialised past ... are subject to the continuous "play" of history, culture and power'.

On the one hand, fragmented identities of difference and diversity are important. On the other hand, the ability of people within groups to hold multiple and segmented identities and engage in a 'politics of sameness' and 'difference' (Nagel 2002), or to position themselves differently over time and space, is also significant. This stresses the importance of the 'situational nature of identity construction', which leads to 'negotiation strategies' that cannot be ignored (Matthews 2002: 77-8). However, such strategies of essentialized national identities, albeit positioned and dynamic ones, may ignore potential feelings of ambivalence and 'in-between-ness' that exist and are seen as difficult and/or problematic; these also need to be explored within constructions of diasporic nationalism and political unity.

\section{Conclusions}

In this article I have discussed constructions of diasporic nationalism and national identity as well as the nation in relation to first- and second-generation Palestinians living in Athens. I have stressed the need to acknowledge such constructions as active 
and strategic, rather than as 'given' in relation to discussions on diasporic identity. Although it is useful to discuss the identities and lives of those in diaspora as social constructions, and as fluid and ambivalent, I have argued that it is also important to understand how individuals actively seek to come together in groups to construct notions of national identity and political unity, particularly if they are seeking an independent state. As Wimmer and Glick Schiller (2002) argue, the processes of nation-state building that affect those in diaspora need adequate exploration. Although analysis of long-distance or diasporic nationalism may be seen as verifying or cementing the importance of the nation, such a process often relies on cross-border connections and, above all, is dynamic in the sense that there may be selective use of times, places and spaces to help construct 'fictive unity', national identities or 'imagined communities'. The choice to 'belong' or imagine one's ties and affiliation to a particular nation or nations reflects the salience of the argument that those in diaspora may be involved in disrupting the notion that the nation is a 'given' even as they themselves may utilize strategic and potentially homogenized notions of unity, ethnicity, religion and national identity.

Research on diasporic identities needs to take into account the constructions of national identity and unity within diasporas that continue to be important and that may or may not be extreme. In some instances, such as in the case of Palestinians in Athens, such constructions may become active strategies to deal with exile, insecurity and displacement and are negotiated as an aspect of ambivalent diasporic identities within which there are particular uses of time, space and place. However, the political need for unity has often meant that such ambivalence and feelings of disunity and detachment are seen as detrimental to the cause and may be difficult to articulate, particularly for the first generation.

Lindholm Schulz (2003: 204) argues that there has been a 'thinning out' of Palestinian identities and of attachment to homeland within the Palestinian diaspora. She claims that this 'runs the risk of diminishing the political strength of the Palestinian movement, which is why stories ... (of difficulties, disillusionment, apathy, integration and so forth) are kept out of official deliberations on what it means to be Palestinian'. What such official depictions ignore, however, is that ambivalence and 'in-between-ness' does not necessarily lead to political apathy or disunity, but that feelings of disillusionment and hope, attachment and detachment to the homeland, all form part of the negotiations about being Palestinian in diaspora and that difficulties as a result are to be expected and acknowledged. There are many different, dynamic constructions of what it means to be Palestinian in diaspora in Athens, which are engaged in 'an unending process of tying and loosening' (Shapiro 2000: 96, citing Nancy 1991) through (and of) time and space.

An interdisciplinary approach is useful for the exploration and grounding of such practices and perceptions in relation to cross-border connections or (dis)connections, for the process can help unravel how different times, places and spaces may come together in disjointed, complex ways. At the same time, in-depth research is needed to examine the material consequences of this in terms of, for example, the constructions 
of boundaries, difference and similarity and consequent inclusion or exclusion, particularly because the relationship between 'those on the move' and states are often tenuous and difficult. As boundaries between and within states continue to be problematic, how migrants and those in diaspora attempt to deal with such boundaries, cross-border connections, (dis)connections and states, either in their host country, homeland or home country through politicized constructions of national identity and belonging, will continue to be important.

\section{Acknowledgements}

My research on Palestinians in diaspora was made possible by Economic and Social Research Council (ESRC) doctoral funding (PTA 030-2002-00600). I would like to thank the Palestinians in Athens to whom I spoke during this research, Cheryl McEwan for her support and guidance, and Joe Painter for reading and commenting on an earlier draft. I also am grateful for the comments and advice given by three anonymous referees. I would also like to thank David Featherstone and his colleagues in the Geography Department at the University of Liverpool for organizing a conference on the Geographies of Transnational Networks in May 2005, where I presented a paper on my research and which enabled me to clarify and refine many theoretical ideas.

\section{References}

Al-Ali, N. and K. Koser (eds) (2002) New approaches to migration? Transnational communities and the transformation of home, London: Routledge.

Aoudé, I. G. (2001) 'Maintaining culture: reclaiming identity: Palestinian lives in the diaspora', Asian Studies Review, 25, 153-67.

Anderson, B. (1983) Imagined communities, London: Verso.

Anderson, B. (1992) 'The new world disorder', New Left Review, 193, 3-14.

Ashcroft, B. and P. Ahluwalia (1999) Edward Said: the paradox of identity, London:

Routledge.

Baumgarten, H. (2005) 'The three faces/phases, of Palestinian nationalism, 19482005', Journal of Palestine Studies, 34, 25-48.

Bhatt, C. and P. Mukta (2000) 'Hindutva in the West: mapping the antimonies of diaspora nationalism', Ethnic and Racial Studies, 23, 407-41.

Billig, M. (1995) Banal nationalism, London: Sage.

Blunt, A. (2005) Domicile and diaspora: Anglo-Indian women and the spatial politics of home, London: Blackwell.

Bowman, G. (1994) '"A country of words": conceiving the Palestinian nation from the position of exile', in E. Laclau (ed.) The making of political identities, London: Verso, 138-70.

Bowman, G. (2003) 'Constitutive violence and the national imaginary: antagonism and defensive solidarity in "Palestine" and "Former Yugoslavia"', Social Anthropology, 11, 319-40.

Brubaker, R. (1996) Citizenship and nationhood in France and Germany, Cambridge: Harvard University Press.

Carter, S. (2005) 'The geopolitics of diaspora', Area, 37, 54-63. 
Christou, A. (2006) 'American dreams and European nightmares: experiences and polemics of second generation Greek-American returning migrants', Journal of Ethnic and Migration Studies, 32, 831-45.

Clifford, J. (1997) Routes: travel and translation in the late twentieth century, Cambridge: Harvard University Press.

Cohen, R. (1997) Global diasporas, London: UCL Press.

Croucher, S. L. (2003) 'Perpetual imagining: nationhood in a global era', International Studies Review, 4, 1-24.

Dirlik, A. (2006) 'Intimate others: [private] nations and diaspora in an age of globalisation', Inter-Asia Cultural Studies, 5, 491-502.

Dorai, M. K. (2002) 'The meaning of homeland for the Palestinian diaspora: revival and transformation', in N. Al Ali and K. Koser (eds) New approaches to migration?

Transnational communities and the transformation of home, London: Routledge, 87-95. Dwyer, C. (2002) 'Where are you from? Young British South Asian women and the making of home', in A. Blunt and C. McEwan (eds) Postcolonial geographies, London: Continuum, 184-200.

Gellner, E. (1983) Nations and nationalism, Oxford: Blackwell.

Glick Schiller, N. and G. Fouron (1999) 'Terrains of blood: Haitian transnational social fields', Ethnic and Racial Studies, 22, 340-66.

Glick Schiller, N. and G. Fouron (2001) Georges woke up laughing: long distance nationalism and the search for home, Durham: Duke University Press.

Glick Schiller, N., L. Basch and C. Blanc-Szanton (1999) 'Transnationalism: a new framework for understanding migration', in S. Vertovec and R. Cohen (eds) Migration, diasporas and transnationalism, Cheltenham: Elgar, 299-314.

Guarnizo, L. E. and M. P. Smith (1998) 'The locations of transnationalism', in M. P. Smith and L. E. Guarnizo (eds) Transnationalism from below, New Brunswick, NJ: Transaction Publishers, 3-33.

Hall, S. (1999) 'Cultural identity and diaspora', in S. Vertovec and R. Cohen (eds) Migration, diasporas and transnationalism, Cheltenham: Elgar, 299-314.

Hanafi, S. (2005) 'Reshaping geography: Palestinian community networks in Europe and the new Media', Journal of Ethnic and Migration Studies, 31, 581-98.

Hobsbawm, E. (1990) Nations and nationalism since 1780, Cambridge: Cambridge University Press.

Howard, S. and J. Gill (2001) "It's like we're a normal way and everyone else is different": Australian children's constructions of citizenship', Educational Studies, 27, 87-103.

Itzigsohn, J. (2000) 'Immigration and the boundaries of citizenship: the institutions of immigrants' political transnationalism', International Migration Review, 34, 1126-54. Karmi, G. (2002) In search of Fatima: a Palestinian story, London: Verso. Kennedy, P. and V. Roudometof (eds) (2002) Communities across borders: new immigrants and transnational cultures, London: Routledge. Khalidi, R. (1997) Palestinian identity: the construction of modern national consciousness, New York: Columbia University Press.

Kurien, P. (2005) 'Being young, brown and Hindu: the identity struggles of second generation Indian Americans', Journal of Contemporary Ethnography, 34, 434-69. 
Lavie, S. and T. Swedenberg (1996) 'Introduction: displacement, diaspora and geographies of identity', in S. Lavie and T. Swedenberg (eds) Displacement, diaspora and geographies of identity, Durham, NC: Duke University Press, 1-15.

Levitt, P. and M. Waters (eds) (2002) The changing face of home: the transnational lives of the second generation, New York: Russell Sage Foundation.

Lindholm Schulz, H. (2003) The Palestinian diaspora: formation of identities and politics of homeland, London: Routledge.

Matar, D. (2006) 'Diverse diasporas, one meta-narrative: Palestinians in the UK talking about 11 September 2001', Journal of Ethnic and Migration Studies, 32, 1027-40. Matthews, K. C. (2002) 'Boundaries of diaspora identity: the case of Central and East African- Asians in Canada', in P. Kennedy and V. Roudometof (eds) Communities across borders: new immigrants and transnational cultures, London: Routledge, 68-82. Mavroudi, E. (forthcoming) Palestinians and pragmatic citizenship: negotiating relationships between citizenship and national identity in diaspora, Geoforum. Nagel, C. (2002) 'Constructing difference and sameness: the politics of assimilation in London's Arab communities', Ethnic and Racial Studies, 26, 258-87.

Østergaard-Nielsen, E. (2001) The politics of migrants' transnational political practices, ESRC Transnational Communities Working Paper WPTC-01-22, http://www.transcomm. ox.ac.uk.

Østergaard-Nielsen, E. (2003) 'The democratic deficit of diaspora politics: Turkish Cypriots in Britain and the Cyprus issue', Journal of Ethnic and Migration Studies, 29, 683-700.

Portes, A. and R. Rumbaut (2001) Legacies: the story of the immigrant second generation, Berkeley: University of California Press.

Portes, A., L. E. Guarnizo and P. Landolt (1999) 'The study of transnationalism: pitfalls and promises of an emergent research field', Ethnic and Racial Studies, 22, 217-37. Pryke, S. (2003) 'British Serbs and long distance nationalism', Ethnic and Racial Studies, 26, 152-72.

Rassool, N. (1999) 'Flexible identities: exploring race and gender issues among a group of immigrant pupils in an inner city comprehensive school', British Journal of Sociology of Education, 20, 23-36.

Robins, K. and A. Aksoy (2001) 'From spaces of identity to mental spaces: lessons from Turkish-Cypriot cultural experience in Britain', Journal of Ethnic and Migration Studies, 27, 685-711.

Said, E. (1986) After the last sky: Palestinian lives, London: Vintage.

Said, E. (1990) 'Reflections on exile', in R. Ferguson, M. Gever, T. Minh-ha and C. West (eds) Out there: marginalization and contemporary cultures, Cambridge, MA: MIT Press, 357-66.

Shapiro, M. J. (2000) 'National times and other times: re-thinking citizenship', Cultural Studies, 14, 79-98.

Shawa, S. (2005) 'Palestinians in Greece: same sense of belonging, diverse communities', in A.

Shiblak (ed.) The Palestinian diaspora in Europe: challenges of dual identity and adaptation, Shaml (The Palestinian Diaspora and Refugee Centre) and the Institute of Jerusalem Studies. Available online at http://www.rsc.ox.ac.uk/PDFs/Shiblak.pdf. 
Shiblak, A. (2000) 'Palestinian refugee communities in Europe: an overview', Paper given at a conference on Palestinian refugee communities in Europe, May, St Antony's College, Oxford, in association with the Refugee Studies Centre, and Shaml (The Palestinian Diaspora and Refugee Centre).

Skrbis, Z. (1999) Long-distance nationalism: diasporas, homelands and identities, Aldershot: Ashgate Publishing.

Smith, H. (2002) 'Greece unites in condemnation of Israel', Guardian, 12 April.

Soysal. Y. (2000) 'Citizenship and identity: living in diasporas in post-war Europe', Ethnic and Racial Studies, 23, 1-15.

Thompson, A. (2001) 'Nations, national identities and human agency: putting people back into nations', The Sociological Review, 49, 18-32.

Werbner, P. (2000) 'Introduction: the materiality of diaspora - between aesthetic and "real" politics', Diaspora, 9, 5-20.

Wimmer, A. and N. Glick Schiller (2002) 'Methodological nationalism and beyond:

nation-state building, migration and the social sciences', Global Networks, 2, 301-34.

Yeoh, B. and S. Huang (2000) 'Home and away: foreign domestic workers and negotiations of diasporic identity in Singapore', Women's Studies International Forum, 4, 413-29.

Yeoh, B. and K. Willis (1999) "'Heart and wing", nation and diaspora: gendered discourses of Singapore's regionalisation process', Gender, Place and Culture, 6, 35572.

Yuval-Davis, N. (1997) Gender and nation, London: Sage. 